\title{
Anion content in Russian rice samples due to increased adaptability to dehydration
}

\author{
Yulia Goncharova ${ }^{1,3, *}$, Nadezhda Gapishko ${ }^{1}$, Nikolay Ochkas ${ }^{1,3}$, and Sergey Goncharov ${ }^{2}$ \\ ${ }^{1}$ Federal Research Center for Rice, 350921 Krasnodar, Belozerny 3, Russia \\ ${ }^{2}$ Kuban State Agrarian University, 350000 Krasnodar, Russia \\ 3"Aratai" LTD, "Skolkovo", 143026 Moscow, Russia
}

\begin{abstract}
Dehydration is characteristic of plants when exposed to a number of stresses: drought, salinity, high and low temperatures, and the defense mechanisms against it are similar when exposed to various stressors. The mechanism of adaptation to salinity in different plants is not the same. But the increased content of chloride and sulfate ions can indirectly release salt-tolerant specimens with a tolerance mechanism that provides the possibility of greater accumulation of salts without harm to the plant. The content of $\mathrm{Cl}$ - ions varied in 50 studied rice samples from 7.6 - 55\%. In terms of the amount of sulfate ions, the range of variation was also high, from $1,19 \%$ to $46,51 \%$. The content of nitrate ions varied least of all in the test material (from $0.37 \%$ to $15,22 \%$ ). 10 samples had a $\mathrm{Cl}$ ion content of more than $30 \%$, which allows them to be recommended as sources according to the characteristic, these are the varieties: Privolniy, Vizit, Courage, Rapan, Smuglyanka. Anahit, Olympus. The varieties Privolniy Mars, Gamma, Olympus contained a high concentration of nitrate ions. Sulfate ions accumulated most of all in the following samples: Anahit, Vizit, Orion, Istok, Regulus. The isolated samples can be sources of both adaptability to drought and salinity.
\end{abstract}

\section{Introduction}

Dehydration is characteristic of plants under the influence of a number of stresses: drought, salinity, high and low temperatures, and the defense mechanisms against it are similar under various stressors [1-3]. So salt tolerance is based on the mechanisms of salt metabolism and accumulation. From saline soils, ions penetrate into plants through the root system and accumulate in the cells of both vegetative and generative organs. The concentration of salts in the cell, which does not affect metabolism, differs depending on the type of plants, the adaptability of their cytoplasm and the level of soil salinity [4-6]. Adaptation has a number of varieties from the development of subcellular and biochemical mechanisms of salt tolerance to molecular ones. In salt-localizing plants, excess salt is concentrated in individual organs or organelles. Saline release it through the secretory system.

\footnotetext{
*Corresponding author: yuliya_goncharova_20@mail.ru
} 
The effective barrier and selective function of the root provides a third group of salt resistance. In the cells of the fourth root, the absorbed $\mathrm{Na}+$ ions are resorbed from the xylem back into the apoplast. A decrease in the water potential in plants is possible with the accumulation of ions or osmolytes in the cell [7-9]. The listed mechanisms of salt tolerance stabilize the water and osmotic potential of the plant cell during drought [10-12]. The amount of Cl- ions is different both in plant organs and in different species and varieties. Their higher content in the leaves creates a gradient of water potential, salt tolerant species were significantly different in terms of the trait. That is, the mechanism of adaptability to salinity in different plants is not the same [13-15]. However, an increased content of chloride and sulfate ions can indirectly release salt-tolerant samples with a tolerance mechanism that provides the possibility of a greater accumulation of salts without harm to the plant [16-18].

\section{Material and methods}

The content of anions was determined in 50 varieties of domestic breeding and collection samples of FNC rice. For measurements we used Kapel 105-M and Infralum devices. For analysis, material was selected from 20 plants of each sample, in duplicate. Sample preparation to obtain data on the anion content included the selection of plant material (1 gram of the sample), its homogenization, fixation with $10 \%$ alcohol, holding in the refrigerator for 1 day, centrifugation at 10-15 thousand rpm, and $2 \mathrm{ml}$ of the supernatant. test tube for analysis. The analysis on the Kapel 105-M device was carried out in accordance with the methods for the determination of trace elements. Statistica software was used for statistical processing of the data obtained. The amount of anions was expressed as a percentage per sample volume.

\section{Results and discussion}

Analysis of variance showed the reliability of the difference between the samples in the composition of the anions (table 1).

Table 1. Analysis of variance for the reliability of the differences in the composition of the anions

\begin{tabular}{|c|c|c|c|c|c|}
\hline Signs & Sum. quad & Degr. freed. & Sr. quad & F & p \\
\hline Chloride, \% & 17052,19 & 47,00 & 362,81 & 3023,44 & 0,00 \\
\hline Nitrate, \% & 1550,10 & 47,00 & 32,98 & 274,84 & 0,00 \\
\hline Sulfate, \% & 11657,03 & 47,00 & 248,02 & 2066,85 & 0,00 \\
\hline
\end{tabular}

The content of $\mathrm{Cl}$ - ions varied in the rice samples from 7,6 - $55 \%$. 10 samples had a content of more than $30 \%$, which allows them to be recommended as sources on the basis of these varieties: Privolniy, Vizit, Courage, Anahit, Olympus (table 2). 
Table 2. Variability of samples by the composition of anions

\begin{tabular}{|c|c|c|c|}
\hline Variety & Chloride, \% & Nitrate, $\%$ & Sulfate, $\%$ \\
\hline Chinese & 12,77 & 2,33 & 12,66 \\
\hline Anahit & 35,66 & 8,45 & 46,11 \\
\hline Natasha & 13,19 & 4,20 & 10,42 \\
\hline Sonnet & 14,78 & 5,39 & 18,85 \\
\hline Favorite & 30,27 & 4,44 & 18,97 \\
\hline Polevik & 23,12 & 3,98 & 28,41 \\
\hline Sturdy & 20,90 & 5,40 & 18,59 \\
\hline Caprice & 14,18 & 2,36 & 15,72 \\
\hline Moor & 17,45 & 2,26 & 5,53 \\
\hline Olympus & 35,08 & 10,41 & 5,19 \\
\hline Yuzhny & 19,38 & 0,79 & 6,62 \\
\hline Atlant & 22,08 & 0,68 & 8,12 \\
\hline Ivushka & 18,88 & 1,12 & 10,23 \\
\hline Zlata & 31,05 & 1,16 & 14,97 \\
\hline Visit & 47,39 & 2,21 & 32,82 \\
\hline Orion & 33,13 & 8,23 & 30,25 \\
\hline Gamma & 22,99 & 11,03 & 14,97 \\
\hline Flagship & 12,62 & 7,53 & 6,92 \\
\hline Source & 28,67 & 8,71 & 33,23 \\
\hline Courage & 54,64 & 8,21 & 23,14 \\
\hline Esaul & 9,87 & 7,46 & 8,61 \\
\hline Regulus & 27,69 & 7,50 & 32,41 \\
\hline Amber & 13,38 & 5,62 & 18,89 \\
\hline Svetlana & 11,69 & 1,98 & 6,47 \\
\hline Assol & 10,99 & 1,64 & 14,04 \\
\hline Mulatto & 25,23 & 0,57 & 26,00 \\
\hline Grace & 14,81 & 8,15 & 16,88 \\
\hline Konstantin & 20,86 & 7,41 & 18,25 \\
\hline Day Night & 15,62 & 4,03 & 18,19 \\
\hline Rain & 14,41 & 4,90 & 25,00 \\
\hline Pearl & 10,48 & 3,64 & 18,91 \\
\hline Birch & 7,81 & 1,96 & 6,88 \\
\hline Diamond & 15,12 & 5,30 & 16,68 \\
\hline Mustang & 20,68 & 5,62 & 6,98 \\
\hline Sonata & 19,39 & 1,26 & 13,74 \\
\hline Rapan & 47,79 & 1,75 & 22,88 \\
\hline Victoria & 23,23 & 6,51 & 25,74 \\
\hline Free & 41,52 & 14,82 & 29,21 \\
\hline Patriot & 17,05 & 2,28 & 10,78 \\
\hline Bullfinch & 15,36 & 2,16 & 9,70 \\
\hline Smuglyanka & 38,02 & 3,80 & 20,31 \\
\hline Aurora & 16,27 & 1,74 & 21,41 \\
\hline Dong Nong & 10,28 & 5,74 & 1,39 \\
\hline Innovator & 8,11 & 4,75 & 13,09 \\
\hline Mars & 16,16 & 13,05 & 18,41 \\
\hline Leader & 14,36 & 3,52 & 14,18 \\
\hline Fisht & 23,52 & 4,88 & 24,14 \\
\hline Yakhont & 15,72 & 6,09 & 15,02 \\
\hline Mean & 21,53 & 4,94 & 17,41 \\
\hline $\mathrm{LSD}_{05}$ & 0,41 & 0,32 & 0,19 \\
\hline
\end{tabular}


These varieties also have a higher sulfate ion content. In terms of the amount of sulfate ions, the range of variation was also high, from $1,19 \%$ to $46,51 \%$. The content of nitrate ions varied least of all in the test material (from $0,37 \%$ to $15,22 \%$ ), (table 3 ).

Table 3. The range of variation of samples in the composition of anions

\begin{tabular}{|c|c|c|c|c|}
\hline Signs & $\begin{array}{c}\text { Average } \\
\text { value }\end{array}$ & Minimum & Maximum & $\begin{array}{c}\text { Standard } \\
\text { deviation }\end{array}$ \\
\hline Chloride, \% & 21,53 & 7,61 & 55,04 & 0,91 \\
\hline Nitrate, \% & 4,94 & 0,37 & 15,22 & 0,28 \\
\hline Sulfate, \% & 17,41 & 1,19 & 46,51 & 0,75 \\
\hline
\end{tabular}

The study of correlations showed the relationship between the content of chloride and sulfate ions in the sample (table 4).

Table 4. Correlation relationships between the composition of the anions of the samples

\begin{tabular}{|c|c|c|c|c|c|}
\hline Signs & Average & $\begin{array}{c}\text { Standard } \\
\text { deviation }\end{array}$ & Chloride, \% & Nitrate, \% & Sulfate, \% \\
\hline Chloride, \% & 20,89 & 10,53 & 1,00 & 0,24 & $\mathbf{0 , 5 5}$ \\
\hline Nitrate, \% & 4,93 & 3,19 & 0,24 & 1,00 & 0,31 \\
\hline Sulfate, \% & 17,31 & 8,64 & $\mathbf{0 , 5 5}$ & 0,31 & 1,00 \\
\hline
\end{tabular}

\section{Conclusion}

The content of $\mathrm{Cl}$ - ions varied in the rice samples from 7,6 - $55 \%$. In terms of the amount of sulfate ions, the range of variation was also high, from $1,19 \%$ to $46,51 \%$. The content of nitrate ions varied least of all in the test material (from $0,37 \%$ to $15,22 \%$ ). Ten samples had its content of $\mathrm{Cl}$ ions - more than $30 \%$, which allows them to be recommended as sources according to the characteristic, these are the varieties: Privolniy, Vizit, Kurazh, Rapan, Smuglyanka. Anahit, Olympus. The varieties Privolniy Mars, Gamma, Olympus contained a high concentration of nitrate ions. Sulfate ions accumulated most of all in the following samples: Anahit, Vizit, Orion, Istok, Regulus. The isolated samples can be sources of both adaptability to drought and salinity.

This work was carried out with the financial support of the Russian Science Foundation No. 19-1600064.

\section{References}

1. J.K. Gontcharova, S.V. Goncharov, E.M. Kharitonov, Russian Journal of Genetics, 54, 7, 796-804 (2018)

2. E.M. Kharitonov, Y.K. Goncharova, E.A. Maliuchenko, Russian Journal of Genetics, 7, 6, 684-697 (2017)

3. V. Derycke, G.E. Vandeputte, R. Vermeylen, W. De Man, B. Goderis, M.H.J. Koch, and J.A. Delcour, J. Cereal Sci., 42, 3, 334-343 (2005)

4. F. Ologundudu, O. Kekere, International Journal of Life Sciences Research, 4, 2, 178186 (2016)

5. R. T Wang, N. M Fernadez, G. T. Henriques, Journal of Experimental Botany, 48, 325331 (2012)

6. O. Kekere, American Journal of Experimental Agriculture, 4, 1842-1852 (2014) 
7. M. H. Khan, S. K. Panda, Acta Physiology of Plant, 30, 81-89 (2008)

8. K. Zhu, Annual Review of Plant Biology, 53, 247- 273 (2002)

9. R.T Mansour, Annual Review of Plant Physiology and Plant Molecular Biology, 51,463-499, (2005)

10. N.M. Noelle, W.P. Weru, S.J. Rodrigue, G Karlin, African J. of Agricultural research, 13, 25, 1257-1271 (2018)

11. T.S. Zinolabedin, P.M. Hemmatollah, A.M. Seyed, B. Hamidreza, Pakistan Journal of Biological Sciences, 11, 1303-1309 (2008)

12. R.B. Yadaw, S. Dixit, A. Raman, K.K. Mishra, P. Vikram, B.P. Swamy, M.T. Cruz, P.T. Maturan, M. Pandey, A. Kumar, Field. Crops Research, 144, 281-287 (2013)

13. H. Koksel, T. Masatcioglu, K. Kahraman, S. Ozturk, A. Basman, J. Cereal Sci., 47, 275282 (2003)

14. A.A. Shaibu, M.I. Uguru, M. Sow, A.T. Maji, M.N. Ndjiondjop, R. Venuprasad, Crop Science, 58, 133-142 (2018)

15. S. Ozturk, H. Koksel, K. Kahraman, P.K. Ng, Food Chem., 83, 4 (2009).

16. S.K. Sah, K.R. Reddy, J. Li, Front. Plant Sci., 7, (2016).

17. C. Salazar, C. Hernández, M.T. Pino, Chilean Journal of Agricultural Research 75, 7179 (2015)

18. M. Hassan, J. Chaura, M.P. Lopez-Gresa, O. Borsai, E. Daniso, M.P. Donat-Torres, Front Plant Sci., 7, 473, (2016) 